\title{
Exhaust Plume Effects on Sonic Boom for a Delta Wing and a Swept Wing-Body Model
}

Raymond Castner

Glenn Research Center, Cleveland, Ohio

Troy Lake

Wichita State University, Wichita, Kansas 


\section{NASA STI Program . . . in Profile}

Since its founding, NASA has been dedicated to the advancement of aeronautics and space science. The NASA Scientific and Technical Information (STI) program plays a key part in helping NASA maintain this important role.

The NASA STI Program operates under the auspices of the Agency Chief Information Officer. It collects, organizes, provides for archiving, and disseminates NASA's STI. The NASA STI program provides access to the NASA Aeronautics and Space Database and its public interface, the NASA Technical Reports Server, thus providing one of the largest collections of aeronautical and space science STI in the world. Results are published in both non-NASA channels and by NASA in the NASA STI Report Series, which includes the following report types:

- TECHNICAL PUBLICATION. Reports of completed research or a major significant phase of research that present the results of NASA programs and include extensive data or theoretical analysis. Includes compilations of significant scientific and technical data and information deemed to be of continuing reference value. NASA counterpart of peer-reviewed formal professional papers but has less stringent limitations on manuscript length and extent of graphic presentations.

- TECHNICAL MEMORANDUM. Scientific and technical findings that are preliminary or of specialized interest, e.g., quick release reports, working papers, and bibliographies that contain minimal annotation. Does not contain extensive analysis.

- CONTRACTOR REPORT. Scientific and technical findings by NASA-sponsored contractors and grantees.
- CONFERENCE PUBLICATION. Collected papers from scientific and technical conferences, symposia, seminars, or other meetings sponsored or cosponsored by NASA.

- SPECIAL PUBLICATION. Scientific, technical, or historical information from NASA programs, projects, and missions, often concerned with subjects having substantial public interest.

- TECHNICAL TRANSLATION. Englishlanguage translations of foreign scientific and technical material pertinent to NASA's mission.

Specialized services also include creating custom thesauri, building customized databases, organizing and publishing research results.

For more information about the NASA STI program, see the following:

- Access the NASA STI program home page at http://www.sti.nasa.gov

- E-mail your question via the Internet to help@ sti.nasa.gov

- Fax your question to the NASA STI Help Desk at $443-757-5803$

- Telephone the NASA STI Help Desk at 443-757-5802

- Write to: NASA Center for AeroSpace Information (CASI) 7115 Standard Drive Hanover, MD 21076-1320 


\section{Exhaust Plume Effects on Sonic Boom for a Delta Wing and a Swept Wing-Body Model}

Raymond Castner

Glenn Research Center, Cleveland, Ohio

Troy Lake

Wichita State University, Wichita, Kansas

Prepared for the

50th Aerospace Science Conference

sponsored by the American Institute of Aeronautics and Astronautics

Nashville, Tennessee, January 9-12, 2012

National Aeronautics and

Space Administration

Glenn Research Center

Cleveland, Ohio 44135 
Trade names and trademarks are used in this report for identification only. Their usage does not constitute an official endorsement, either expressed or implied, by the National Aeronautics and Space Administration.

This work was sponsored by the Fundamental Aeronautics Program at the NASA Glenn Research Center.

Level of Review: This material has been technically reviewed by technical management.

Available from

NASA Center for Aerospace Information 7115 Standard Drive

Hanover, MD 21076-1320
National Technical Information Service 5301 Shawnee Road Alexandria, VA 22312

Available electronically at http://www.sti.nasa.gov 


\title{
Exhaust Plume Effects on Sonic Boom for a Delta Wing and a Swept Wing-Body Model
}

\author{
Raymond Castner \\ National Aeronautics and Space Administration \\ Glenn Research Center \\ Cleveland, Ohio 44135 \\ Troy Lake \\ Wichita State University \\ Wichita, Kansas 67260
}

\begin{abstract}
Supersonic travel is not allowed over populated areas due to the disturbance caused by the sonic boom. Research has been performed on sonic boom reduction and has included the contribution of the exhaust nozzle plume. Plume effect on sonic boom has progressed from the study of isolated nozzles to a study with four exhaust plumes integrated with a wing-body vehicle. This report provides a baseline analysis of the generic wing-body vehicle to demonstrate the effect of the nozzle exhaust on the near-field pressure profile. Reductions occurred in the peak-to-peak magnitude of the pressure profile for a swept wing-body vehicle. The exhaust plumes also had a favorable effect as the nozzles were moved outward along the wing-span.
\end{abstract}

\section{Nomenclature}

AOA Angle of attack, degrees

$B \quad$ Nozzle boat-tail angle, degrees

$c \quad$ Airfoil chord, in.

D Nozzle diameter (outer), in.

$h$ Distance below vehicle, in.

$L_{v} \quad$ Vehicle length, in.

$\mathrm{M}_{\infty} \quad$ Free-stream Mach number

NPR Nozzle pressure ratio $=P_{t} / P_{\infty}$

$P \quad$ Local static pressure, psia

$P_{t} \quad$ Total pressure in nozzle, psia

$P_{\infty} \quad$ Free-stream static pressure, psia

$\triangle P \quad P-P_{\infty}$

$\triangle P / P \quad\left(P-P_{\infty}\right) / P_{\infty}$

$T_{\mathrm{o}} \quad$ Nozzle total temperature, $\mathrm{R}$

$T_{\infty} \quad$ Free-stream total temperature, $\mathrm{R}$

$t \quad$ Airfoil thickness, in.

$x \quad$ Distance along abscissa of pressure signature, in.

$y \quad$ Distance from nozzle centerline, in. 


\subsection{Introduction}

Supersonic travel is not allowed over populated areas due to the disturbance caused by the sonic boom. At the vehicle nose there is a rise in pressure, followed by a steady decrease to negative pressure, followed by a rise to atmospheric pressure. When propagated to the ground, this pressure profile takes the shape of an Nwave. The two large pressure changes create a "double boom" effect. The impact of the sonic boom is so large that the FAA has issued a noise policy for supersonic aircraft stating: "Since March 1973, supersonic flight over land by civil aircraft has been prohibited by regulation in the United States. The Concorde (Ref. 1) was the only civil supersonic airplane that offered service to the United States, and it is no longer in service" (Ref. 2). The same policy also states that "noise operating rules would propose that any future supersonic airplane produce no greater noise impact on a community than a subsonic airplane." Subsonic noise limits are prescribed in 14 CFR Part 36 stage 4.

To create an aircraft with acceptable noise, programs such as the Quiet Spike (Ref. 3) and the Shaped Sonic Boom Demonstrator (SSBD) (Ref. 4) reduced the intensity of the nose shock wave. Most research has been focused on reducing the sonic boom contribution caused at the front of the vehicle, and less research has occurred in reducing the contribution from aft structures or nozzle exhaust. One exception, Putnam (Ref. 5), performed a study of exhaust nozzles and the effects of the exhaust plume. Tests were done in the 4- by 4Foot Supersonic Wind Tunnel with pressure measurements taken one diameter away from the nozzle.

Exhaust nozzle plume effect on sonic boom has progressed from analysis and testing of an isolated nozzle (Refs. 6 and 7), to analysis of a slot nozzle embedded in a simplified wing geometry (Ref. 8), to analysis of a single engine wing-body model (Ref. 9), to the present analysis of a multi engine wing-body model. For the isolated nozzle, it was shown how the lip shock from an under-expanded nozzle plume could suppress the nozzle boat-tail expansion and reduce the trailing shock. Similar results were found for the slot nozzle embedded in the wing, where the trailing shock caused by the wing expansion was reduced by the addition of an under-expanded nozzle plume. Results for a single engine wing-body model also demonstrated a reduction in the trailing shock by including an under-expanded nozzle plume.

The subject of this report is the preliminary study of a simplified wing-body configuration with the addition of four engine exhaust nozzle plumes. The purpose is to provide a baseline analysis of a generic wing-body configuration, and demonstrate the effect of the nozzle exhaust on the vehicle pressure profiles, which could be extrapolated to a sonic boom signature. The Wind-US and Cart3D computational fluid dynamic (CFD) codes were used for this analysis. Three types of nozzle plumes were studied: an axisymmetric convergent-divergent nozzle, an axisymmetric plug nozzle, and a high aspect ratio nozzle. Two vehicle configurations were studied: a $59^{\circ}$ delta wing-body model and a $69^{\circ}$ swept wing-body model. The pressure profiles from these configurations are presented and compared to a baseline vehicle with no propulsion to demonstrate the effect of the nozzle exhaust plume.

\subsection{Computational Modeling}

\section{$2.1 \quad$ Wind-US}

Three types of exhaust nozzles were modeled with Wind-US: (1) a convergent-divergent supersonic nozzle replica of "Nozzle 6" (Ref. 5), (2) a plug nozzle, and (3) a high aspect ratio convergent-divergent supersonic slot nozzle. The configurations will be discussed in Section 3.0. Wind-US is a general purpose fluid flow solver that is used to numerically solve various sets of equations governing physical phenomena (Ref. 10). Wind-US was used to take advantage of the established capability to correctly compute nozzle plumes with viscous and turbulence effects. The code supports the solution of the Euler and Navier-Stokes equations, along with supporting equation sets governing turbulent and chemically-reacting flows. The flow solver is parallel and can take advantage of multi-core and multi-cpu hardware. The version used was WindUS 2.0. Wind-US was used with the modified second-order Roe upwind scheme for stretched grids, implicit time stepping with a Courant-Friedrichs-Lewy (CFL) number of 1.0, and the Menter shear stress transport (SST) turbulence model. 


\subsection{Cart3D}

Two vehicle configurations were studied using Cart3D: (1) a 59 delta wing-body model and (2) a $69^{\circ}$ swept wing-body model. The vehicle configurations were fully three-dimensional models, and will be discussed in Section 3.0. Cart3D is a high-fidelity inviscid analysis package for conceptual and preliminary aerodynamic design. It allows users to perform automated CFD analysis on complex geometry. Geometry for Cart3D is in the form of surface triangulations. These may be generated from within a Computer-Aided Design (CAD) package, from legacy surface triangulations or from structured surface grids. Cart3D uses adaptively refined Cartesian grids to discretize the space surrounding a geometry and cuts the geometry out of the set of "cut-cells" which intersect the surface triangulation. The flow solver is parallel and can take advantage of multi-core and multi-cpu hardware. Solutions used the Cart3D adjoint adaptation module. This module uses adjoint-weighted residual error-estimates to drive mesh adaptation. Once a user specifies outputs of interest (lift, drag, etc.) with a corresponding error tolerance, this module automatically meshes the simulation to drive the remaining numerical errors in the outputs below the requested tolerance. This module has been validated for sonic boom prediction by Wintzer (Ref. 11), and this capability was the reason Cart3D was selected for analysis of this problem. The adaptation module allows greatly reduced time spent on mesh generation and analysis.

\subsection{Geometry Modeling}

\subsection{Nozzles}

For the nozzle configurations, the computational domain was an axisymmetric structured grid which consisted of 8 zones, and 511,299 grid points. The slot nozzle simulation was a similar two-dimensional structured grid. The domain extended 18 nozzle diameters downstream of the nozzle exit. Multi-block wallpacked grids were generated for use on parallel processor systems. Viscous wall boundaries were used for all nozzle surfaces. Convergence was monitored with nozzle mass flow and the off-body pressure profile at 150 in. from the nozzle centerline. External flow conditions were run at Mach 2.2 and an angle of attack of zero. Cases were run on a local computer cluster and took approximately 6 to $8 \mathrm{hr}$ to converge.

\subsubsection{Convergent-Divergent Nozzle}

Figure 1 displays the Mach 2.0 supersonic convergent-divergent exhaust nozzle, which was a replica of the Putnam "Nozzle 6." This nozzle had a design pressure ratio of 8.12 and simulations were performed from NPR $=6$ to 18 . For the wing-body model propulsion-integration analysis, described in Section 3.2, the simulation was performed at an under-expanded pressure ratio of 18 , where a highly under-expanded plume was selected with the intent to demonstrate a significant plume effect. If successful, a NPR closer to the design point would be studied. The CFD grid is shown in Figure 3(a) and the nozzle plume shape in Figure 4(a). The shape of the nozzle plume was extracted from the simulation and imported into grid generation software, where the nozzle plume was modeled as a solid body. Use of solid body models of nozzle plumes was validated by both Putnam (Ref. 5) and Castner (Ref. 9).

\subsubsection{Plug Nozzle}

The plug nozzle was simplified to a single stream nozzle, and was a replica of the Chenoweth (Ref. 12) nozzle core stream only, shown in Figure 2. The design pressure ratio was 26.3 and simulations were performed at NPR $=8,14$, and 18. Again, the wing-body simulation was performed at a NPR $=18$. The CFD grid is shown in Figure 3(b) and the resulting nozzle plume shape in Figure 4(b). For the wingbody model analysis, the plume was extracted from the simulation and imported into grid generation software and the nozzle plume was modeled as a solid body. 


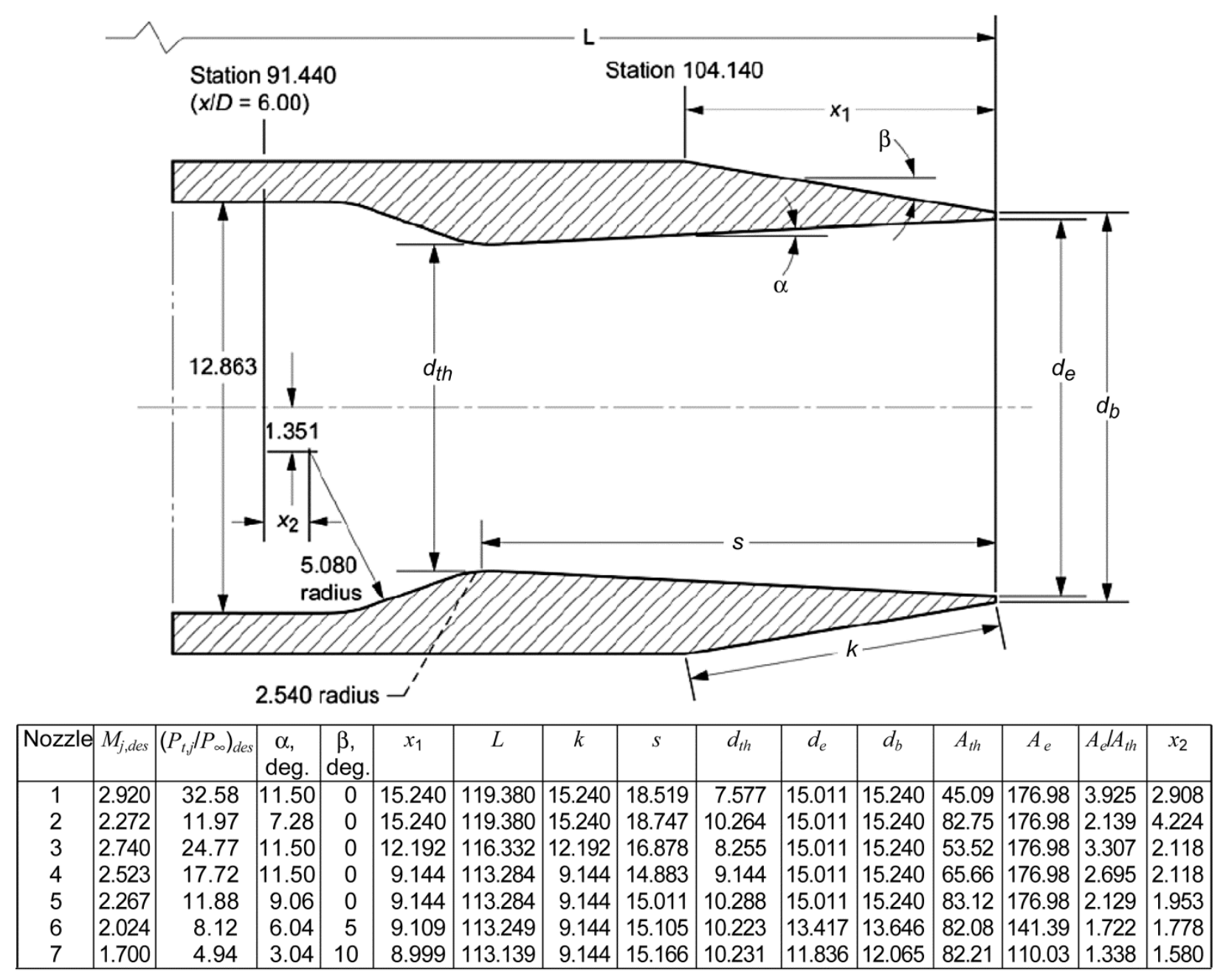

Figure 1.-Convergent-divergent "Nozzle 6" (Ref. 5).

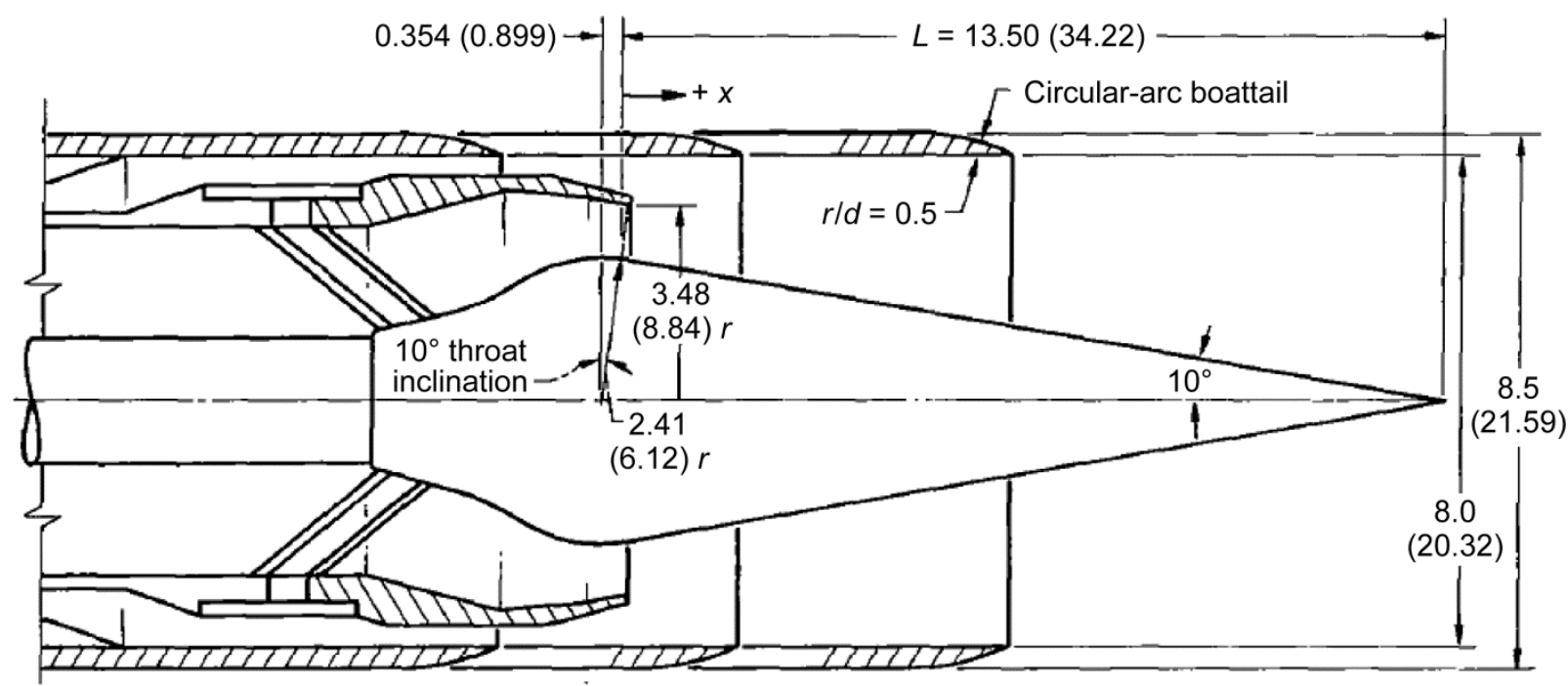

Figure 2.-Plug nozzle (Ref. 12). 


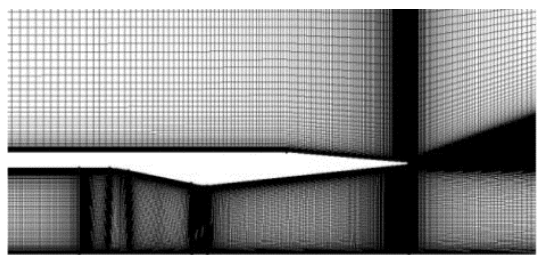

(a)

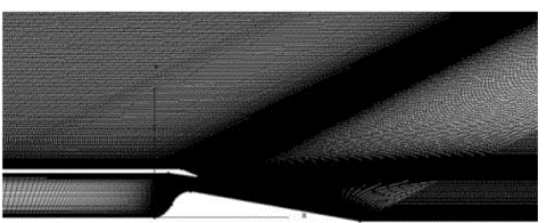

(b)

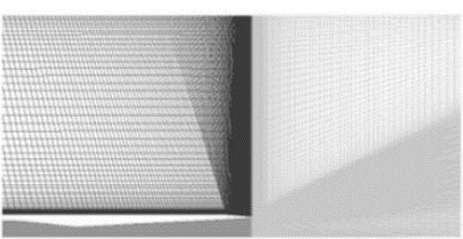

(c)

Figure 3.-Wind-US grid for (a) convergent-divergent nozzle, (b) plug nozzle, and (c) slot nozzle.

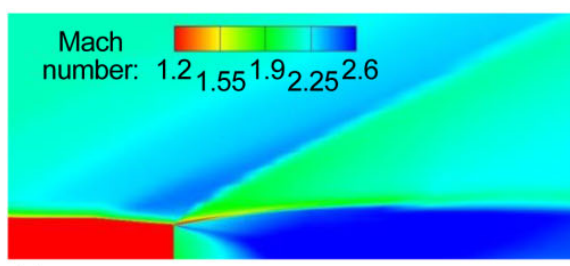

(a)

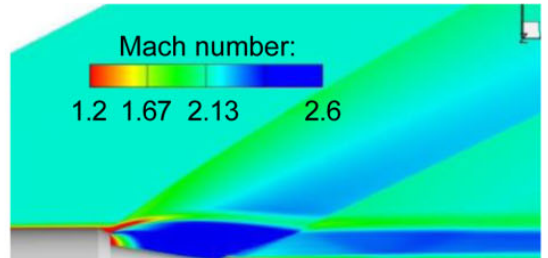

(b)

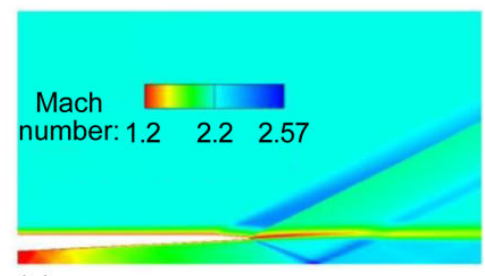

(c)

Figure 4.-Wind-US solutions (Mach number contour) for (a) convergent-divergent nozzle, (b) plug nozzle, and (c) slot nozzle.

\subsubsection{Slot Nozzle}

A fully-expanded Mach 2.2 slot nozzle was designed, operating at a NPR $=12$, for highly underexpanded flow. The NPR $=12$ plume was selected due to the excessive size of the plume at NPR $=18$. The nozzle was a simple convergent-divergent geometry with a throat height of $2.05 \mathrm{in}$. and an exit height of $3.88 \mathrm{in}$. There was a short external boat-tail of $5^{\circ}$, and an external height of $4.57 \mathrm{in}$. The CFD grid is shown in Figure 3(c). In the wing-body analysis, the slot nozzle had an effect on a larger portion of the wing area, so a smaller plume shape at the reduced pressure ratio was selected. The nozzle plume shape (Fig. 4(c)) was extracted from the simulation and imported into grid generation software and the nozzle plume was modeled as a solid body. In the wing-body analysis the nozzle had an aspect ratio of 11.2:1.

\subsection{Vehicles}

Two vehicle configurations, from Hunton (Ref. 13), were studied (Fig. 5): a $59^{\circ}$ delta wing-body model and a $69^{\circ}$ swept wing-body model. Vehicles were studied with a notional 4-engine configuration. Figure 6 shows a comparison between the Concorde (Ref. 1) and the $59^{\circ}$ delta wing-body model, with the scale factor estimated at 9:1. Table 1 shows comparisons between some key aircraft dimensions.

For the Cart3D CFD analysis, the original wing-body vehicle scale was increased by a factor of 14.11, where the vehicle body diameter was modeled as $15.1 \mathrm{in}$. This diameter allowed use of previous modeling work that was performed with the $59^{\circ}$ delta wing-body vehicle and Putnam's "Nozzle 6". At this scale, the notional propulsion was 3.38 in. in diameter (instead of a very small 0.23 in. diameter). Dimensions of the nozzles are given in Table 2. Exit area and throat area were not held constant during this study, and the plug nozzles were nominally 24 percent larger in diameter than the convergentdivergent nozzle. A size for "Nozzle 6" was estimated from the Concorde propulsion system, assuming $10,000 \mathrm{lb}$ of thrust per engine at cruise conditions, and then geometrically reduced to the nominally $1 / 9$ scale difference between the Concorde and the model. When the same procedure was used for the plug nozzle, there was a difference in exit area. 

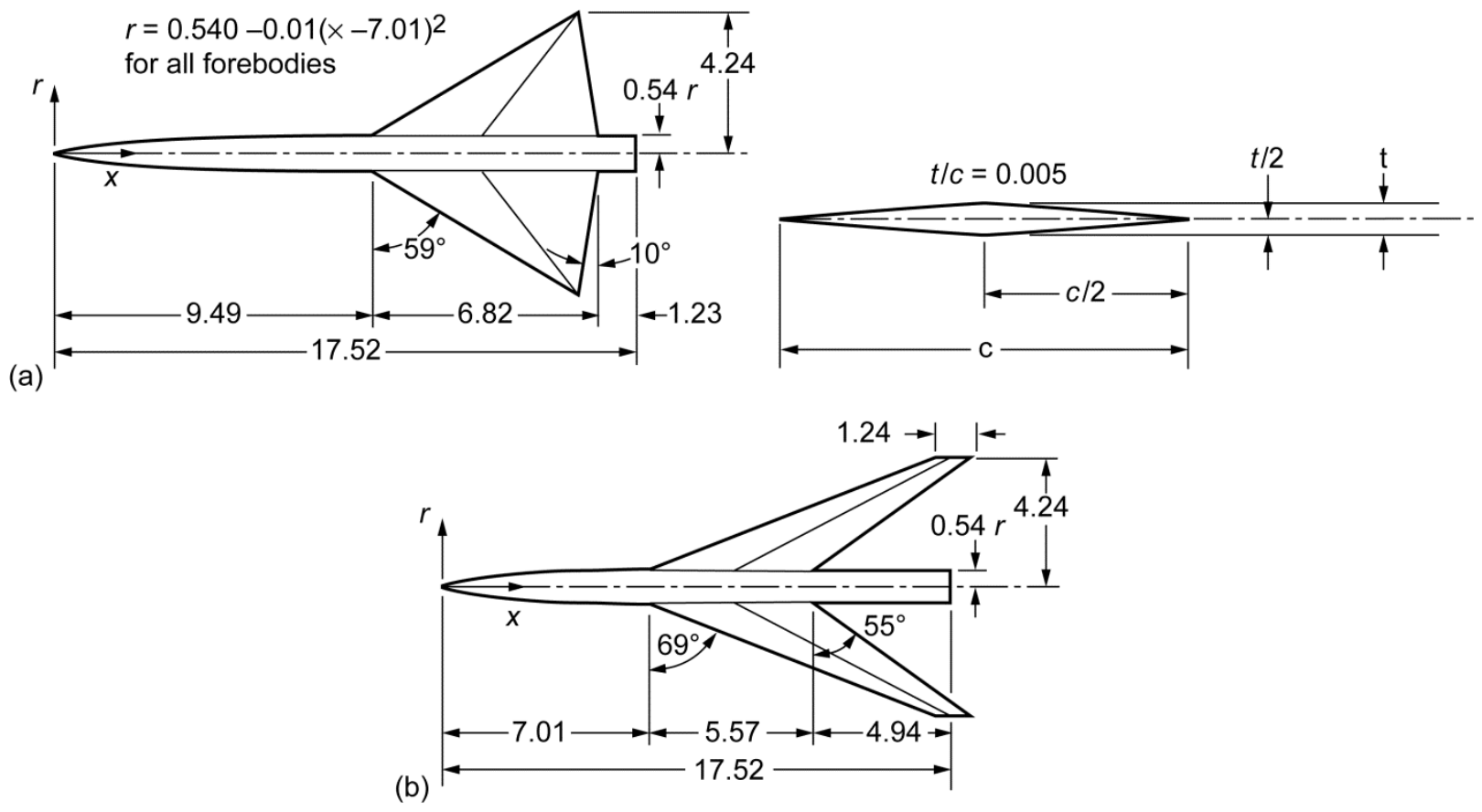

Figure 5.-Dimensions for (a) delta wing-body model and (b) swept wing-body model, before being scaled up by a factor of 14.11 .
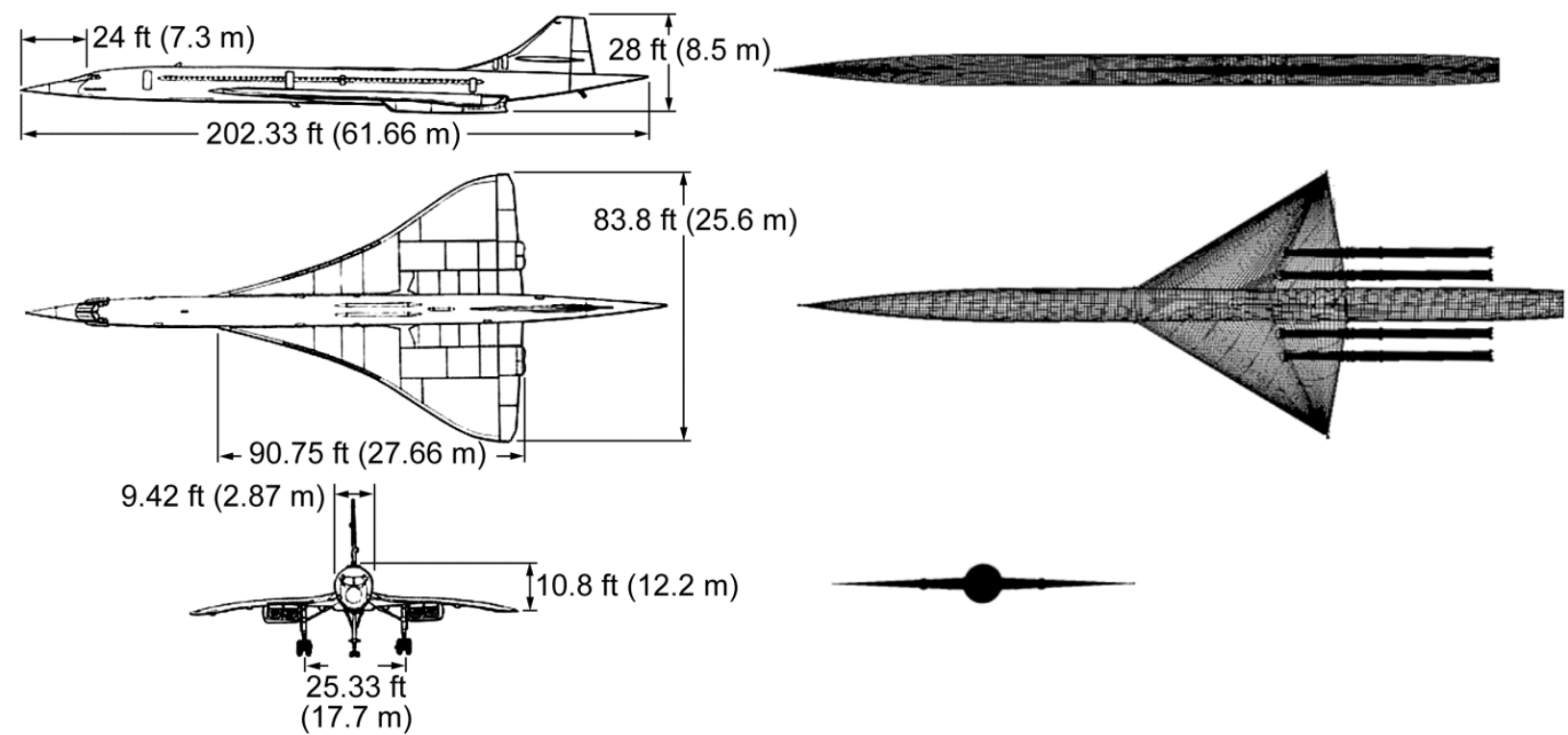

Figure 6.-Comparison of the Concorde (Ref. 1) to the delta wing-body model (scaled to a wingspan of 446 in.). 
TABLE 1.-COMPARISONS BETWEEN THE CONCORDE AND THE 59 DELTA WING-BODY MODEL

\begin{tabular}{|l|c|c|c|c|}
\hline \multicolumn{2}{|c|}{ Concorde } & \multicolumn{2}{c|}{$59^{\circ}$ delta wing-body } & $\begin{array}{c}\text { Scale factor } \\
\text { (Concorde: Delta wing-body dimensions) }\end{array}$ \\
\hline Length & 2428 in. & Length & 247.5 in. & $9.8: 1$ \\
\hline Wing Span & 446 in. & Wing span & 52.3 in. & $8.5: 1$ \\
\hline
\end{tabular}

TABLE 2.-KEY NOZZLE DIMENSIONS

\begin{tabular}{|l|c|c|c|c|c|}
\hline \multicolumn{1}{|c|}{ Nozzle } & NPR & $T_{0}$ & Exit area sq-in. & Exit diameter, in. & Outer diameter, in. \\
\hline Convergent-divergent & 8,18 & $530 \mathrm{R}$ & 2.66 & 3.38 & 3.75 \\
\hline Plug & 8,18 & $530 \mathrm{R}$ & 4.9 & 3.52 & 4.64 \\
\hline & & & & & \\
\hline Slot & $\mathrm{NPR}$ & $T_{0}$ & Exit area sq-in. & Exit width, in. & Exit height, in. \\
\hline
\end{tabular}

The model was run on the Pleiades computer cluster at the NASA Ames Research Center. The adjoint adaptation module uses Open MultiProcessing (OpenMP) for code parallelization within a node, and at the time of writing, could not utilize message passing interface (MPI) to work between nodes, required on Peliades architecture. As a result, a single node with 12 processors was used until the node ran out of memory, at approximately 4.5 million cells.

\subsection{4 $\quad 59^{\circ}$ Delta Wing-Body Model}

The $59^{\circ}$ delta wing-body model was a simplified platform for a propulsion integration study on sonic boom. The wing-body model was modified with a long sting, tapered at the trailing end. The tapered sting was installed to eliminate the effects of a tail cone and tail, so propulsion effects could be studied with a focus on the nozzle plume. The overall length of the body and sting was $398.9 \mathrm{in}$., and the trailing portion of the sting had the same geometry as the nosecone. Engines were installed in an embedded configuration at the back of the wing as shown in Figure 7. Embedded nozzles were used to isolate plume effects, without the effects of an inlet flow field. The engine plumes were constructed of the actual exhaust plume shape, followed by a cylindrical solid body (rectangular solid body for the slot nozzle). The cylindrical portion was extended aft to a point where the termination of the plume would not affect the pressure signature from the nose, wing, and nozzles. The configurations tested with the $59^{\circ}$ delta wing-body model are shown in Table 3, and included three different levels of engine placement (spacing and stagger).

\subsection{5 $\quad 69^{\circ}$ Swept Wing-Body Model}

The $69^{\circ}$ swept wing-body model was used as an alternate platform for propulsion integration studies. The swept wing-body model was also modified with a long sting, tapered at the trailing end, so propulsion effects could be studied with a focus on the nozzle plume. Engines were installed at the back of the wing as shown in Figure 8. Again, embedded nozzles were used to isolate plume effects. For this configuration the engine locations were studied at three positions, locations are shown in Figure 9. The engine plumes were again constructed of the actual exhaust plume shape, followed by a cylindrical solid body. The cylindrical portion was extended aft to a point where the termination of the plume would not affect the pressure signature from the nose, wing, and nozzles. The configurations tested with the $69^{\circ}$ swept wing-body model are also shown in Table 3. 
(a)

(c)

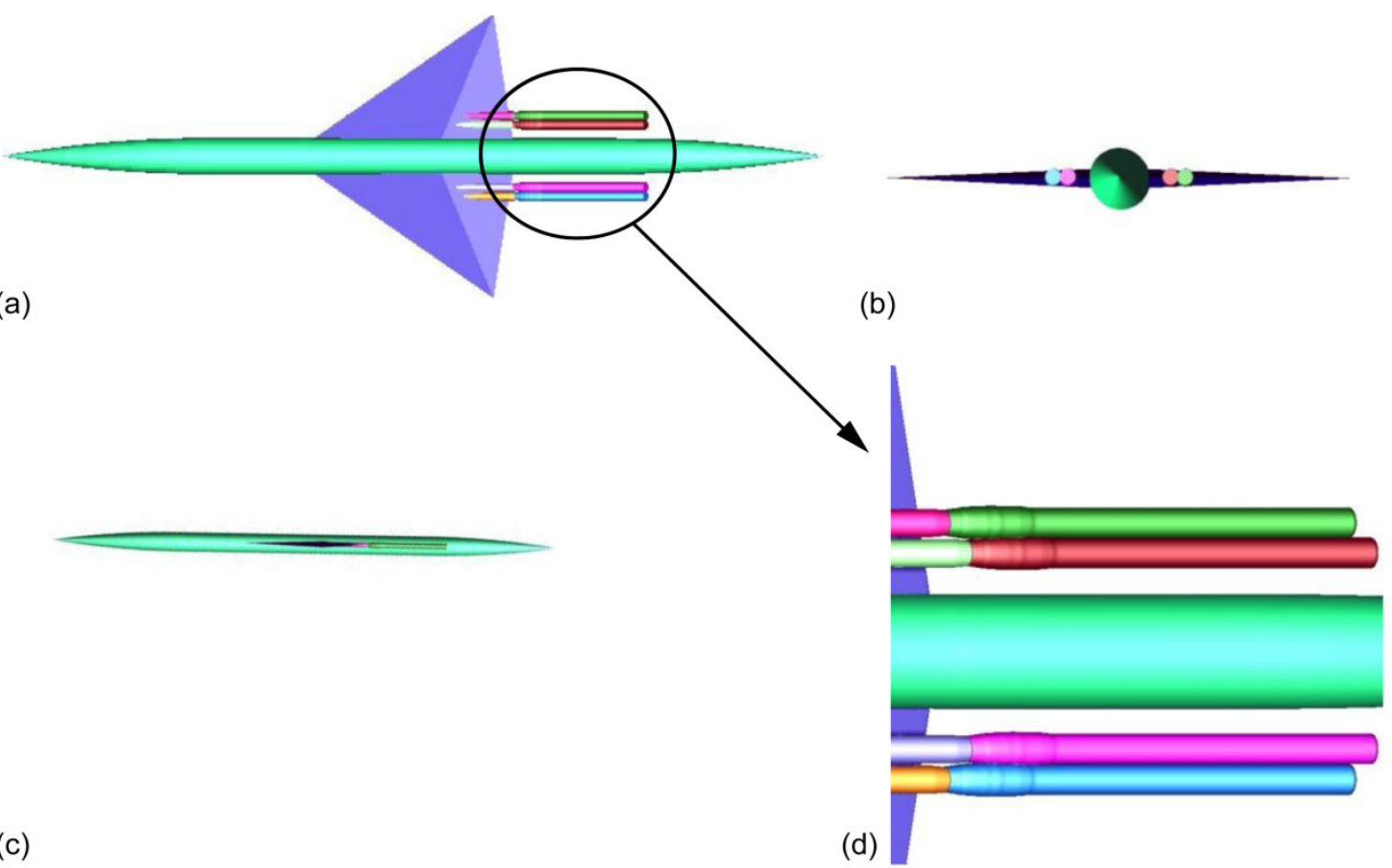

Figure 7.-Cart3D model of the delta wing-body model with convergent-divergent nozzles installed (a) top view, (b) back view, (c) left side view, and (d) plume shape.

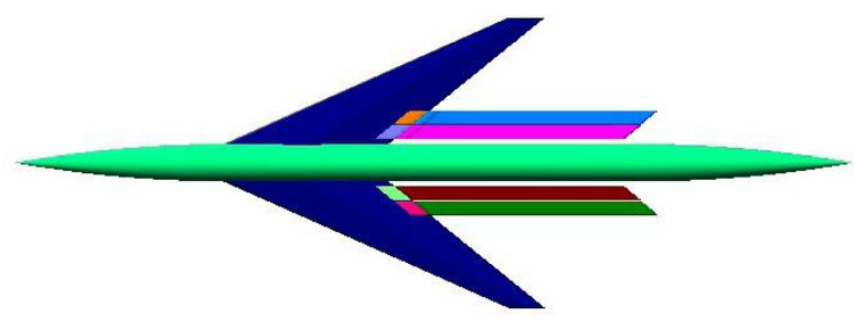

Figure 8.-Cart3D model of the swept wing-body model with slot nozzles installed, top view.

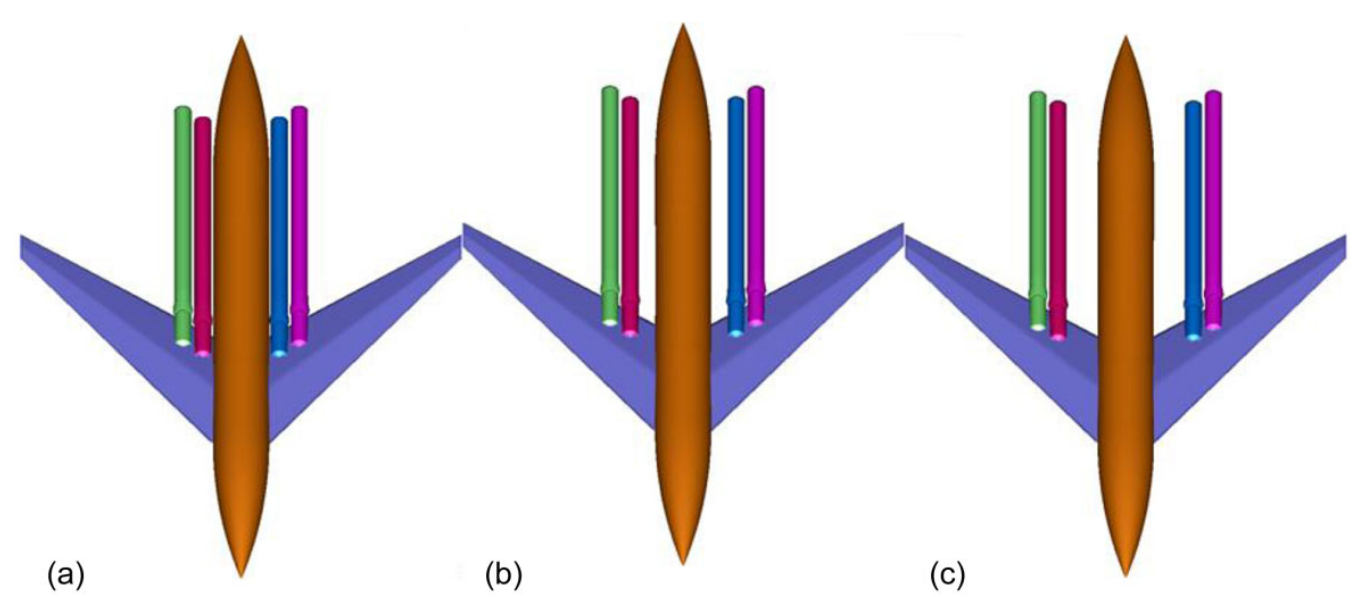

Figure 9.-Cart3D model of the swept wing-body model with convergent-divergent nozzles installed, (a) inner, (b) middle, and (c) outer engine mounting positions. 
TABLE 3.- $-59^{\circ}$ DELTA WING-BODY MODEL AND $69^{\circ}$ SWEPT WING-BODY MODEL CONFIGURATIONS

\begin{tabular}{|l|l|l|c|c|c|c|c|}
\hline Configuration & \multicolumn{1}{|c|}{$\begin{array}{c}\text { Vehicle } \\
\text { type }\end{array}$} & $\begin{array}{c}\text { Nozzle } \\
\text { type }\end{array}$ & $\begin{array}{c}\text { Inboard nozzle } \\
\text { location, in. }\end{array}$ & $\begin{array}{c}\text { Nozzle } \\
\text { spacing, } \\
\text { nozzle } \\
\text { diameters }\end{array}$ & $\begin{array}{c}\text { Nozzle } \\
\text { stagger, } \\
\text { nozzle } \\
\text { diameters }\end{array}$ & NPR & Mach / $T_{\infty}, \mathrm{R}$ \\
\hline C430 & Delta-wing & C-D & 13.17 & 3 & 0 & 18 & $2.2 / 530$ \\
\hline C413 & Delta-wing & C-D & 13.17 & 1 & 3 & 18 & $2.2 / 530$ \\
\hline C410 & Delta-wing & C-D & 13.17 & 1 & 0 & 18 & $2.2 / 530$ \\
\hline P430 & Delta-wing & Plug & 13.17 & 3 & 0 & 18 & $2.2 / 530$ \\
\hline P413 & Delta-wing & Plug & 13.17 & 1 & 3 & 18 & $2.2 / 530$ \\
\hline S451 & Delta-wing & Slot & 12.64 & 1 & 0 & 12 & $2.2 / 530$ \\
\hline C411i & Swept-wing & C-D & 9.5 & 1 & 1 & 8,18 & $2.2 / 530$ \\
\hline C411m & Swept-wing & C-D & 13.5 & 1 & 1 & 8,18 & $2.2 / 530$ \\
\hline C411o & Swept-wing & C-D & 17.5 & 1 & 1 & 8,18 & $2.2 / 530$ \\
\hline P411i & Swept-wing & Plug & 9.9 & 1 & 1 & 8,18 & $2.2 / 530$ \\
\hline P411m & Swept-wing & Plug & 13.9 & 1 & 1 & 8,18 & $2.2 / 530$ \\
\hline P4110 & Swept-wing & Plug & 17.9 & 1 & 1 & 8,18 & $2.2 / 530$ \\
\hline S451 & Swept-wing & Slot & 12.64 & 1 & 0 & 12 & $2.2 / 530$ \\
\hline
\end{tabular}

Configuration code $=\mathrm{C} 411 \mathrm{i}$

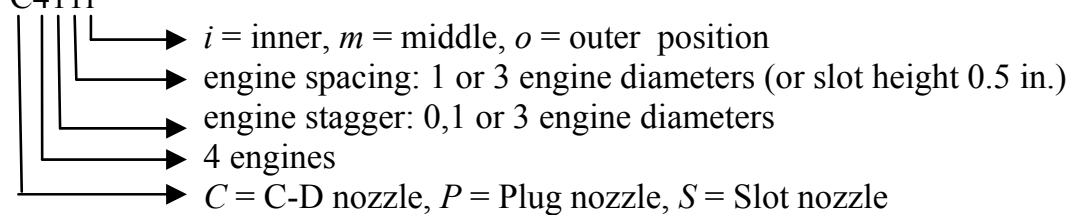

\subsection{Results}

Pressure profiles $(\Delta P / P)$ were computed at three body lengths $\left(h=3 L_{v}\right)$ below the vehicle. Three sets of results will be presented: (1) pressure profiles for the $59^{\circ}$ delta wing-body model at a NPR $=18$, (2) pressure profiles for the $69^{\circ}$ swept wing-body model at a NPR $=18$, and (3) pressure profiles for the $69^{\circ}$ swept wingbody model at a NPR $=8$. Propulsion was analyzed with different levels of engine placement, including spacing and stagger (i.e., one nozzle exit plane located behind the other).

\section{1 $\Delta P / P$ Pressure Profile for $59^{\circ}$ Delta Wing-Body Model}

Pressure profiles are displayed in Figure 10 for the $59^{\circ}$ delta wing-body model at a distance of three vehicle lengths $\left(h=3 L_{v}\right)$ below the vehicle. Major features in these pressure profiles include the nose shock, wing shock, wing expansion, and trailing shock back to ambient pressure. The baseline vehicle pressure signature is the $59^{\circ}$ delta wing-body model with no propulsion installed. Configurations with propulsion installed all had a small reduction in the peak-to-peak magnitude of the pressure profile. It was difficult to differentiate been the pressure profiles for most nozzle installations. Only two configurations demonstrated a small improvement over the others: (a) the slot nozzle configuration and (b) the plug nozzle with a spacing of 3 and no stagger. These results did not demonstrate a significant impact on the overall peak-to-peak magnitude of the pressure profile, and were only useful for a small improvement in the vehicle pressure profile.

\section{2 $\Delta P / P$ Pressure Profile for $69^{\circ}$ Swept Wing-Body Model, NPR $=18$}

Figure 11 shows the pressure profiles at a location three vehicle lengths below the vehicle for the swept wing-body model with convergent-divergent $(C-D)$ nozzles operating at a NPR $=18$. In this case, the pressure profile is characterized by a nose shock, a wing shock, the nozzle lip shock, and the trailing shock. For the C-D nozzles, all configurations showed a favorable reduction in the peak-to-peak value of the pressure profile, when compared to the baseline vehicle with no propulsion. As the engine nacelles were moved from their inboard, to middle, to outboard location along the wing-span, there was a reduction in the magnitude of the trailing shock, which would be favorable for a reduction in sonic boom. 


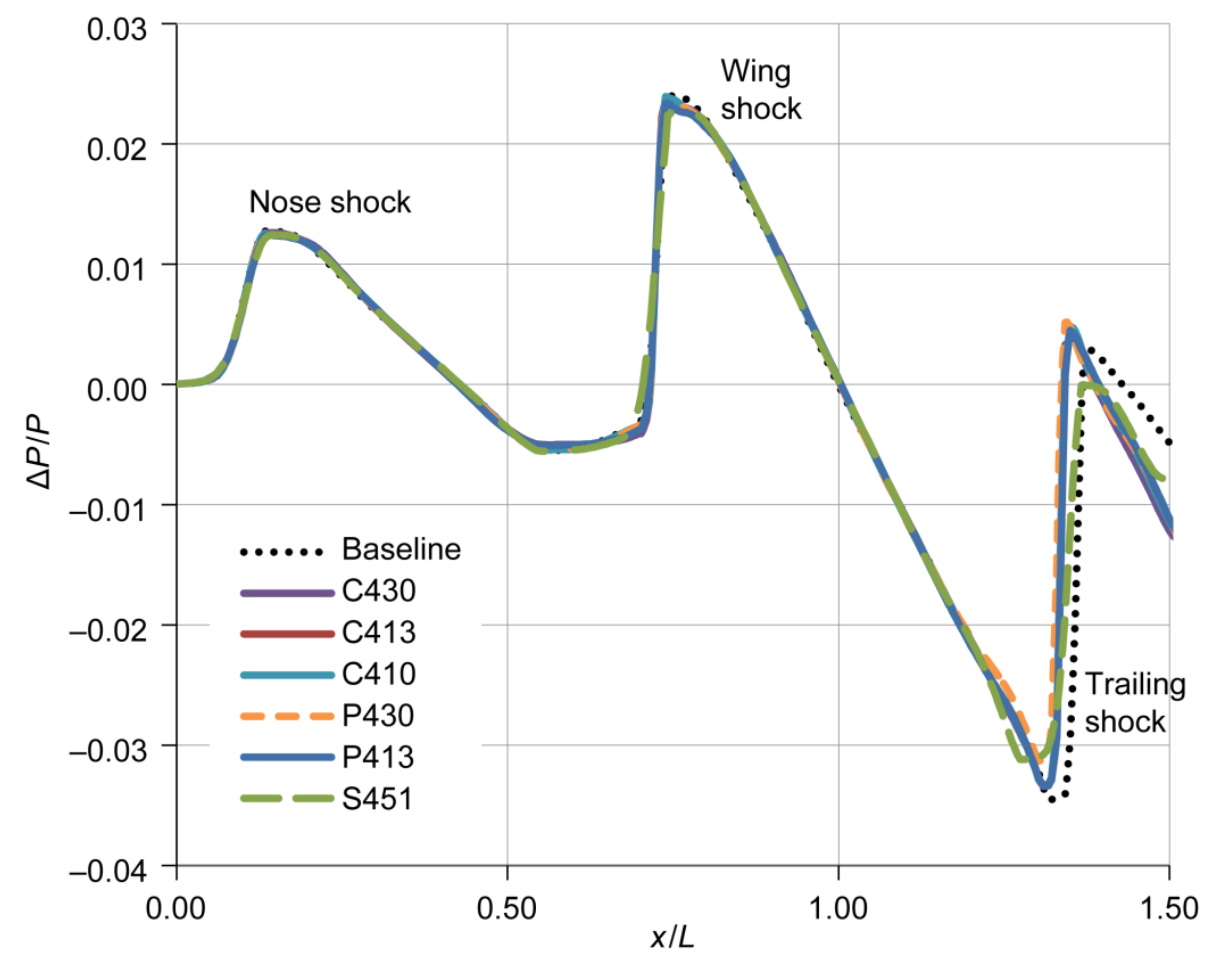

Figure 10.-Delta wing-body pressure profiles $(\Delta P / P)$ at $h=3 L_{V}$ below vehicle.

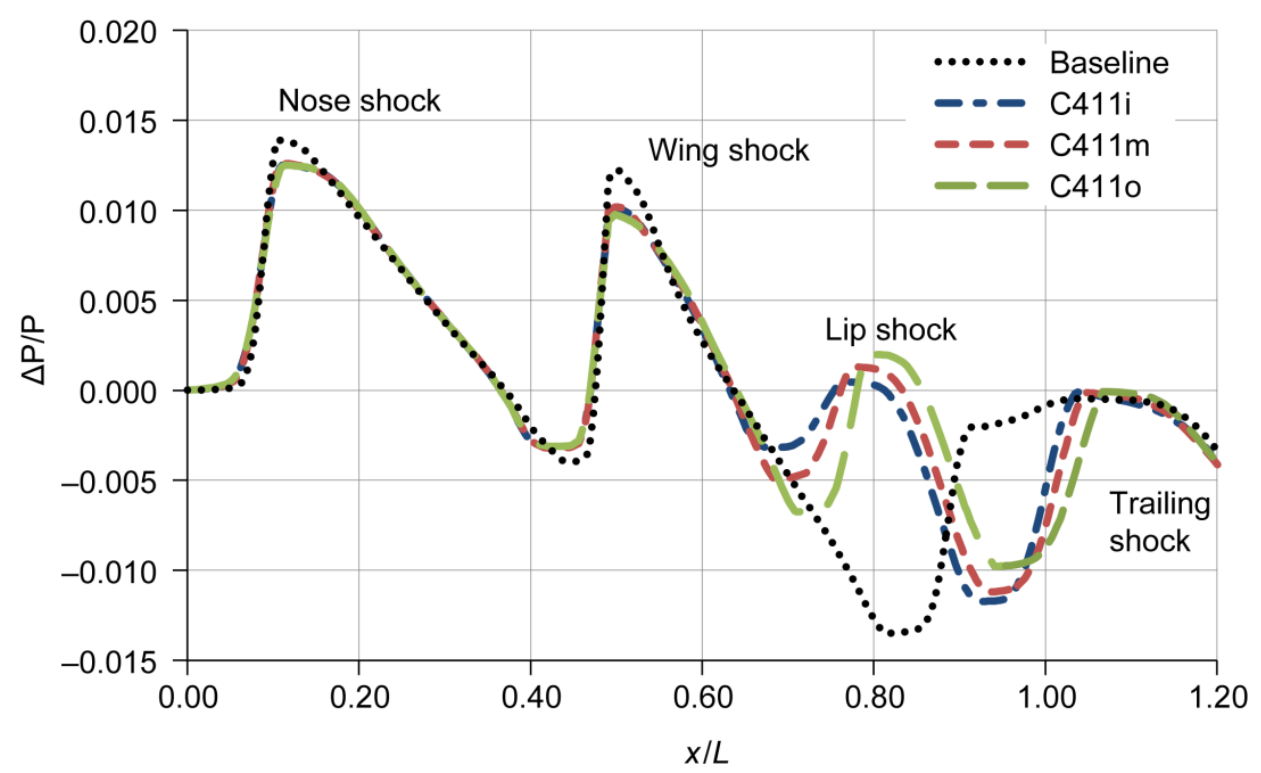

Figure 11.-Swept wing-body pressure profiles $(\Delta P / P)$ for convergent-divergent nozzle configurations, NPR $=18, h=3 L_{V}$ below vehicle. 


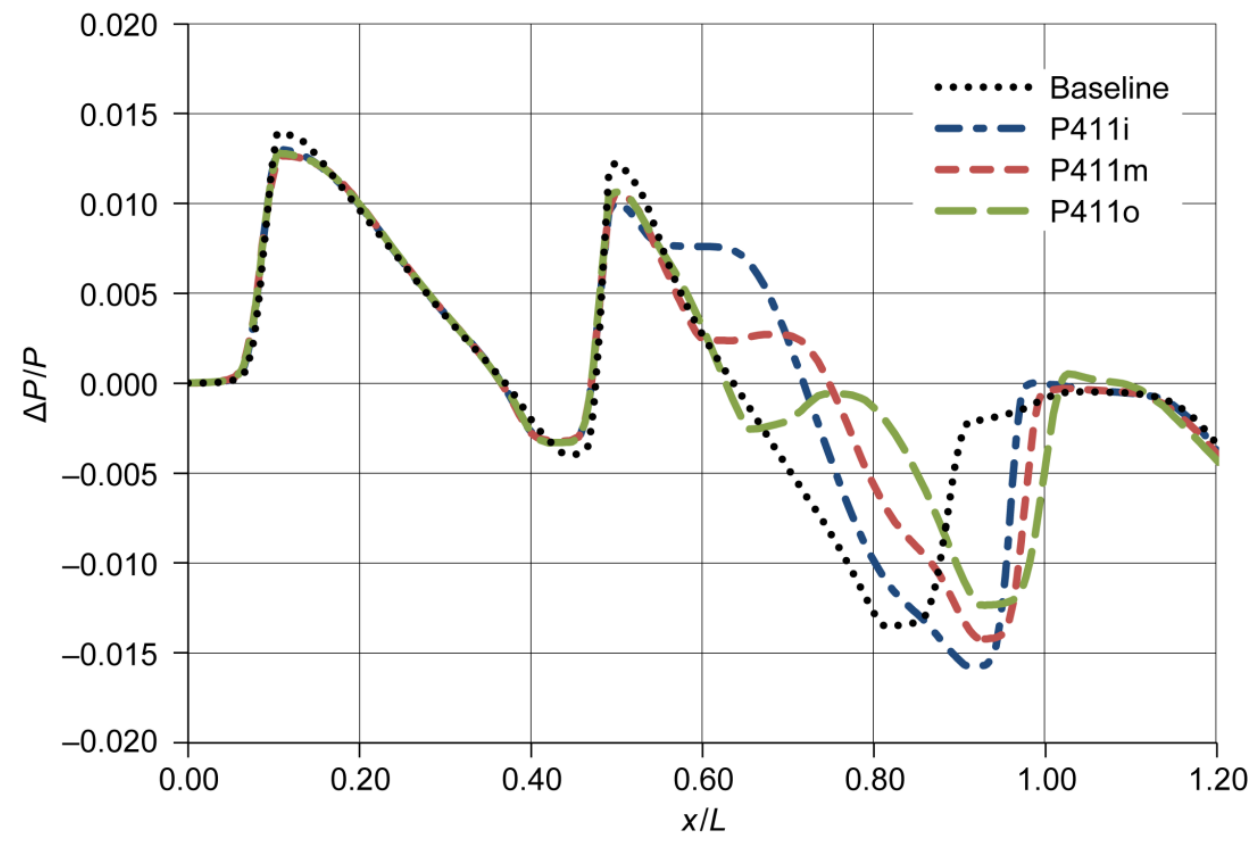

Figure 12.-Swept wing-body pressure profiles $(\triangle P / P)$ for plug nozzle configurations, NPR $=18, h=3 L_{V}$ below vehicle.

Figure 12 shows the pressure profiles for the swept wing-body model with plug nozzles operating at $\mathrm{NPR}=18$, also at three vehicle lengths below the vehicle. When compared to the baseline vehicle with no propulsion, the peak-to-peak pressure profile was increased with the addition of plug nozzles located at the inboard location along the wing-span. As the engines were moved to the middle and outboard locations, the magnitude of the trailing shock decreased. For this study, the plug nozzles were 25 percent larger than the C-D nozzles and were potentially too large to have a beneficial effect on the pressure profile. This type of detrimental effect on sonic boom was previously demonstrated in studies of isolated nozzles where an underexpanded plume reduced the near-field pressure profile for moderate increases in NPR, but a large increase in NPR caused an increase in the peak-to-peak pressure profile (Ref. 6). Results for the slot nozzle case are not shown as it had no improvement over the C-D or the plug nozzle results.

\section{3 $\triangle P / P$ Pressure Profile for $69^{\circ}$ Swept Wing-Body Model, NPR $=8$}

Simulations from the previous section resulted in under-expanded nozzle flow. For the C-D nozzle, the design point was a NPR $=8$. At this point, the thrust coefficient was computed to be 0.99 , but at $\mathrm{NPR}=18$ the thrust coefficient was reduced to 0.91 . To study the effect at the design point, simulations for the swept wing-body geometry were re-calculated using a NPR $=8$.

Figure 13 contains the pressure profiles for the $C$-D nozzles at NPR $=8$. All configurations showed a favorable reduction in the peak-to-peak value of the pressure profile, when compared to the baseline vehicle with no propulsion. Again, as the engine nacelles were moved from their inboard, to middle, to outboard location along the wing-span, there was a reduction in the magnitude of the trailing shock. For the C-D nozzles operating at their design point, these profiles show the benefit that this embedded prolusion configuration has on a generic swept wing vehicle.

Figure 14, shows results for the plug nozzles at NPR $=8$ (on the swept wing-body vehicle). As before, when compared to the baseline vehicle with no propulsion, the peak-to-peak pressure profile was increased with the addition of plug nozzles located at the inboard location along the wing-span. As the engines were moved to the middle and outboard locations, the magnitude of the trailing shock again was 
decreased. These results suggest that the underexpanded plume shape generated by the plug nozzle at $\mathrm{NPR}=18$ was too large to be of benefit for this configuration, but operation at NPR $=8$ showed reductions in the peak-to-peak value of the pressure profile as the engine locations were moved outward. This is again similar to the effect found in isolated nozzle research, where an underexpanded plume reduced the near-field pressure profile for moderate increases in NPR, but a large increase in NPR caused an increase in the peak-to-peak pressure profile.

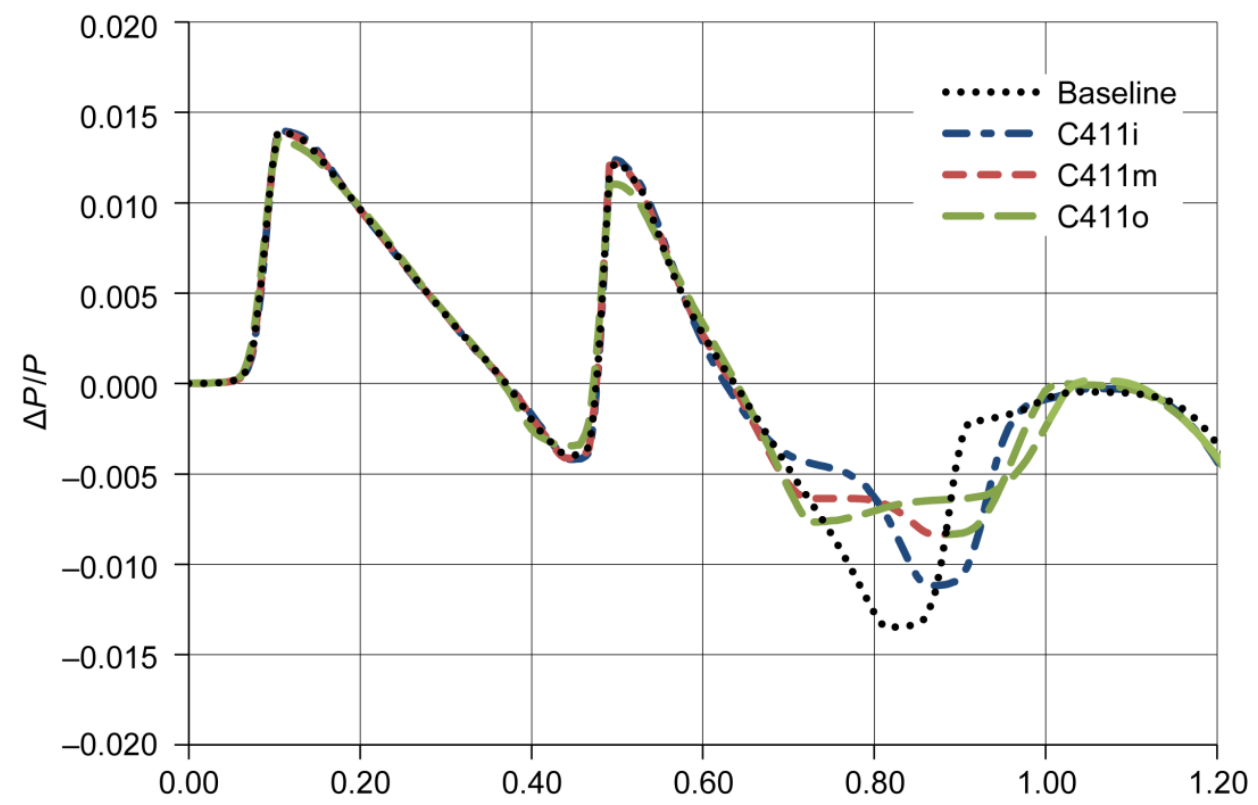

Figure 13.-Swept wing-body pressure profiles $(\triangle P / P)$ for convergent-divergent nozzle configurations, NPR $=8, h=3 L_{V}$ below vehicle.

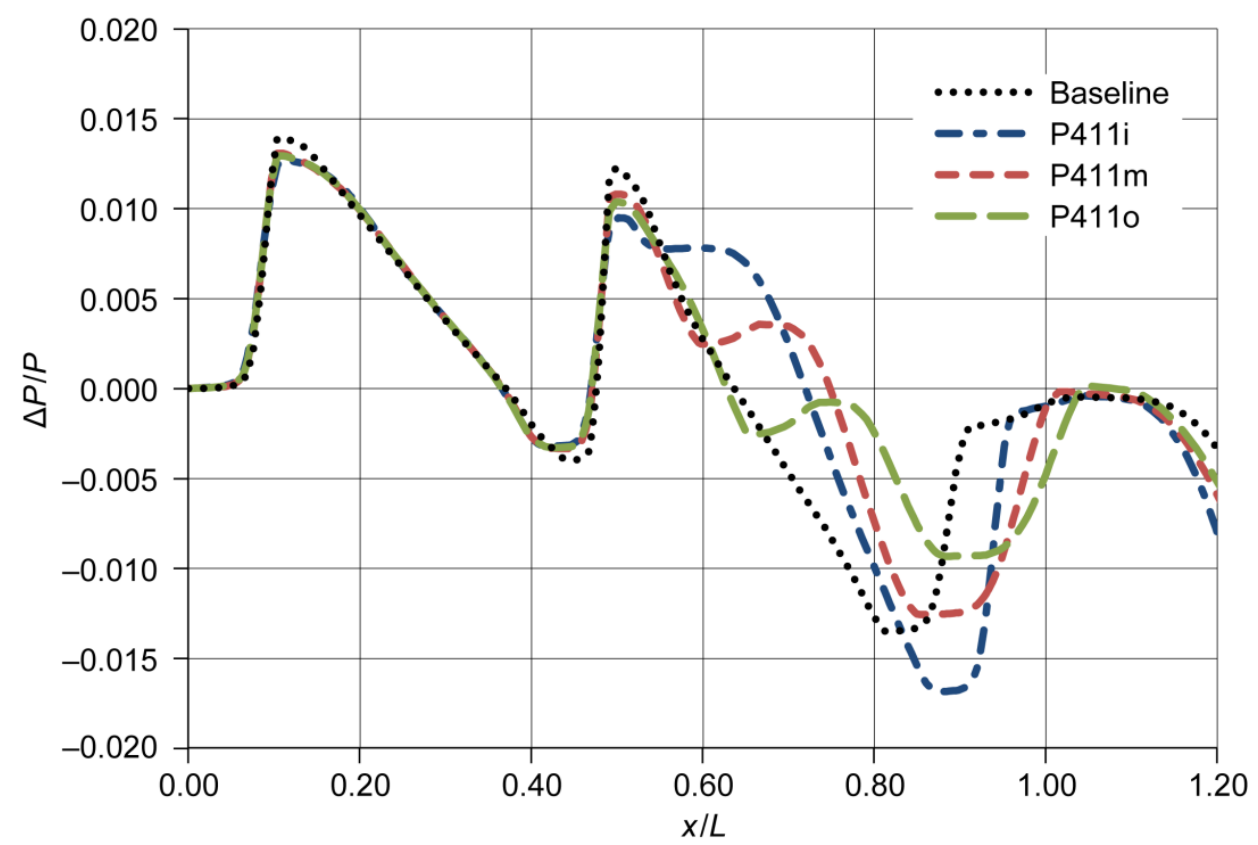

Figure 14.-Swept wing-body pressure profiles $(\triangle P / P)$ for plug nozzle configurations, NPR $=8, h=3 L_{V}$ below vehicle. 


\subsection{Conclusions}

Three types of nozzles and two types of wing-body vehicles were used to study propulsion integration for nozzle plume effects on sonic boom. The study was not intended to be an aircraft design, but an attempt to isolate nozzle plume effects on a simple integrated configuration. The vehicle configuration did not include a tail cone, vertical tail, or horizontal stabilizer.

Results for the delta wing-body vehicle indicated that the three different types of nozzles had a small effect on the overall pressure profile, showing only 10 percent improvement in the trailing shock strength. The shock and expansion wave from the delta wing was stronger than the shock and expansion from the swept wing, and the nozzle lip shock was not able to affect the wing expansion as seen in past studies of isolated nozzles.

Changes in the pressure profile were favorable for the swept wing-body configuration, where convergent-divergent nozzles produced a reduction in the trailing shock. The plug nozzles, when operating at NPR $=8$, also produced a reduction in the trailing shock. The exhaust plumes reduced the peak-to-peak magnitude of the pressure profile as the nozzles were moved outward along the wing-span. Movement of the nozzles resulted in a 28 to a 44 percent reduction in the strength of the trailing shock, depending on nozzle pressure ratio.

This preliminary study utilized a stepping stone approach to focus on how nozzle plumes interact with the wing-body vehicle. Nozzle plume effects for a four engine vehicle have a visible effect on the near field pressure profile. Based on the improvements in near field profiles, the following future analysis are feasible: (1) a design of experiments study to determine optimum nozzle placement and pressure ratio, and (2) a study which includes the addition of the vehicle tail-cone and tail.

\section{References}

1. "Concorde SST: History," Concorde SST, http://www.concordesst.com/history/historyindex.html [retrieved 24 February 2011].

2. "Supersonic Aircraft Noise," http://www.faa.gov/about/office_org/headquarters_offices/ apl/noise_emissions/supersonic_aircraft_noise/[retrieved 5 December 2011].

3. Freund, D., Howe, D., Simmons, F., and Schuester, L., "Quiet Spike Prototype Aerodynamic Characteristics From Flight Test," AIAA-2008-125, Jan. 2005.

4. Graham, D., Dahlin, J., Meredith, K., and Vadnais, J., "Aerodynamic Design of Shaped Sonic Boom Demonstration Aircraft," AIAA-2005-8, Jan. 2005.

5. Putnam, L. and Capone, F., "Experimental Determination of Equivalent Solid Bodies to Represent Jets Exhausting into a Mach 2.20 External Stream," NASA TN-D-5553, 1969.

6. Castner, R.S., "Analysis of Plume Effects on Sonic Boom Signature for Isolated Nozzle Configurations," NASA/TM-2008-215414 (AIAA-2008-3729), June 2008.

7. Bui, T., "CFD Analysis of the Nozzle Jet Plume Effects on Sonic Boom Signature," AIAA-2009-1054, Jan. 2009.

8. Castner, R.S., "Slot Nozzle Effects for Reduced Sonic Boom on a Generic Supersonic Wing Section," AIAA-2010-1386, Jan. 2010.

9. Castner, R.S., "Analysis of Exhaust Plume Effects on Sonic Boom for a 59-Degree Wing Body Model," AIAA-2011-917, Jan. 2011.

10. Towne, C.E., "Wind-US Users Guide, Version 2.0," NASA/TM-2009-215804, Oct. 2009.

11. Wintzer, M., Nemec, M., and Aftosmis, M., "Adjoint-Based Adaptive Mesh Refinement for Sonic Boom Prediction," AIAA-2008-6593, Aug. 2008.

12. Chenoweth, F.C., and Lieberman, A., "Experimental Investigation of Heat-Transfer Characteristics of a Film-Cooled Plug Nozzle With Translating Shroud," NASA TN D-6160, Feb. 1971.

13. Hunton, L., Hicks, R., and Mendoza, J., "Some Effects of Wing Planform on Sonic Boom," NASA TN-D 7160, Jan. 1973. 


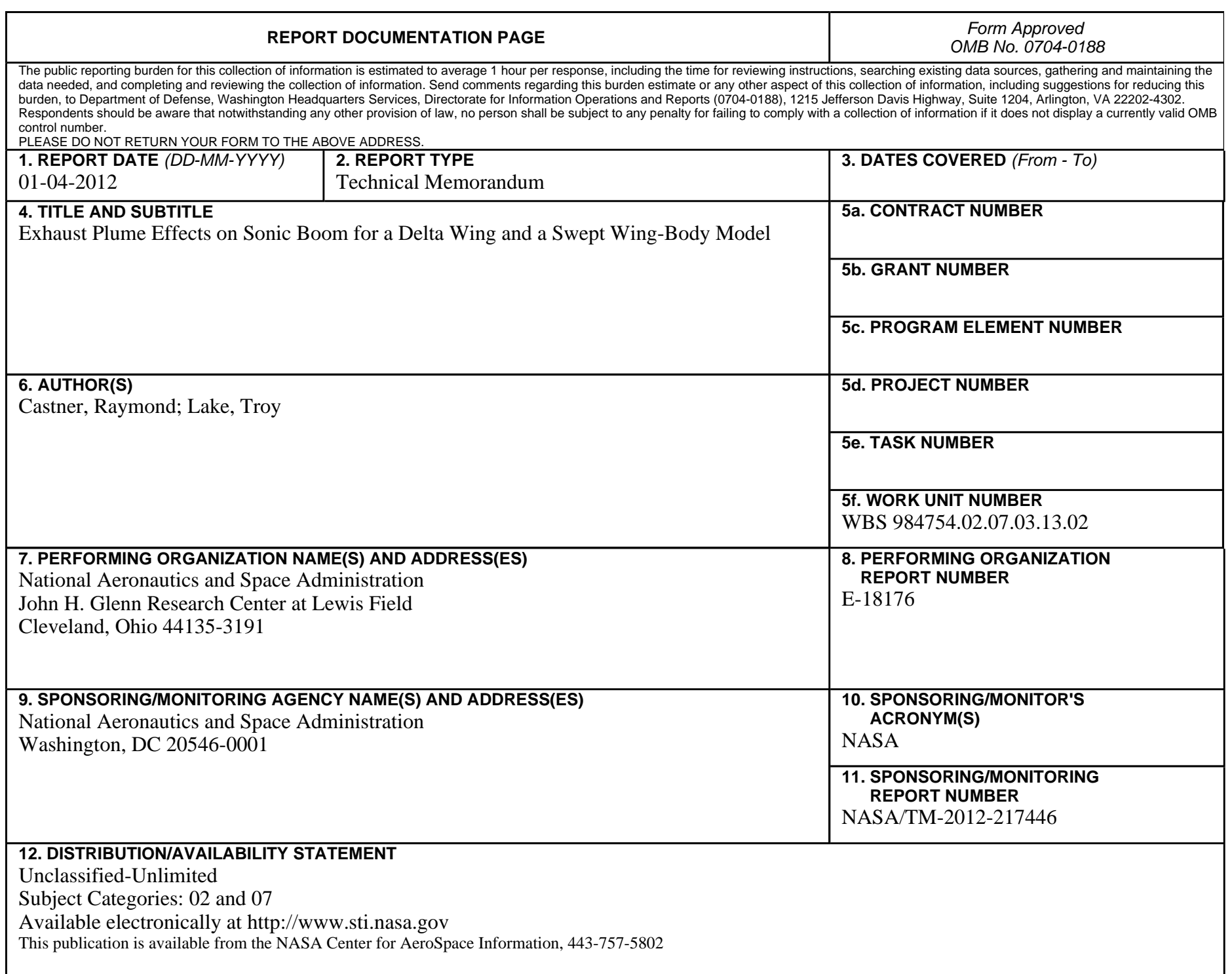

\section{SUPPLEMENTARY NOTES}

\section{ABSTRACT}

Supersonic travel is not allowed over populated areas due to the disturbance caused by the sonic boom. Research has been performed on sonic boom reduction and has included the contribution of the exhaust nozzle plume. Plume effect on sonic boom has progressed from the study of isolated nozzles to a study with four exhaust plumes integrated with a wing-body vehicle. This report provides a baseline analysis of the generic wing-body vehicle to demonstrate the effect of the nozzle exhaust on the near-field pressure profile. Reductions occurred in the peak-to-peak magnitude of the pressure profile for a swept wing-body vehicle. The exhaust plumes also had a favorable effect as the nozzles were moved outward along the wing-span.

\section{SUBJECT TERMS}

Sonic booms; Exhaust nozzle; Computational fluid dynamic (CFD); Exhaust gases; Plumes; Delta wings; Body-wing configurations

\begin{tabular}{|c|c|c|c|c|c|}
\hline \multicolumn{3}{|c|}{ 16. SECURITY CLASSIFICATION OF: } & \multirow{2}{*}{$\begin{array}{l}\text { 17. LIMITATION OF } \\
\text { ABSTRACT } \\
\text { UU }\end{array}$} & \multirow{2}{*}{$\begin{array}{l}\text { 18. NUMBER } \\
\text { OF } \\
\text { PAGES } \\
19\end{array}$} & \multirow{2}{*}{$\begin{array}{l}\text { 19a. NAME OF RESPONSIBLE PERSON } \\
\text { STI Help Desk (email:help@sti.nasa.gov) } \\
\text { 19b. TELEPHONE NUMBER (include area code) } \\
\text { 443-757-5802 }\end{array}$} \\
\hline $\begin{array}{l}\text { a. REPORT } \\
\text { U }\end{array}$ & $\begin{array}{l}\text { b. ABSTRACT } \\
\mathrm{U}\end{array}$ & $\begin{array}{l}\text { c. THIS } \\
\text { PAGE } \\
\text { U }\end{array}$ & & & \\
\hline
\end{tabular}


